Annals of Warsaw University of Life Sciences - SGGW

Land Reclamation No 42 (1), 2010: 23-29

(Ann. Warsaw Univ. of Life Sci. - SGGW, Land Reclam. 42 (1), 2010)

\title{
Ephemeral gully erosion from agricultural regions in the Pacific Northwest, USA
}

\author{
MICHAEL E. BARBER ${ }^{1}$, ROBERT L. MAHLER ${ }^{2}$ \\ ${ }^{1}$ Civil and Environmental Engineering, Washington State University, Pullman, WA \\ ${ }^{2}$ Soil Fertility, University of Idaho, Moscow, ID
}

\begin{abstract}
Ephemeral gully erosion from agricultural regions in the Pacific Northwest, USA. Soil erosion continues to be problematic financially and environmentally with the USEPA ranking sediment as one of the top ten pollutants of concern in the USA. One aspect of erosion often overlooked is the role of ephemeral gullies in terms of quantity of sediment produced and amount exported to nearby waterways. Current physically-based and empirical models are inadequate for predicting this type of erosion particularly at the watershed scale. A new methodology for predicting the quantity and location of sediment delivery was developed and tested via a case study. Aerial ephemeral gully erosion rates varied from $33.6 \mathrm{mton} / \mathrm{km}^{2}$ (0.15 U.S. tons/acre) in the Big Bear Creek basin to $88.4 \mathrm{mton} / \mathrm{km}^{2}$ (0.39 U.S. tons/acre) in the Middle Potlatch Creek basin representing 2.3 to $7.7 \%$ of the total surface sediment load. This information was used to develop a predictive Erosion Potential Index (EPI) that uses LANDSAT aerial imagery combined with readily available soils information and a digital elevation model to identify the most probably locations of ephemeral gully development. High resolution aerial imagery was used to quantify actual ephemeral gully locations which were then compared to the EPI predicted locations to verify the procedure. High resolution aerial imagery was also used to quantify the amounts of soil erosion from ephemeral gullies in basins of the Potlatch River system.
\end{abstract}

Key words: Sediment, Best Management Practices, Erosion Control, Remote Sensing.

\section{INTRODUCTION}

In the U.S. soil erosion research emerged as a national priority following the dust bowl era of the 1930's (Michalson et al. 1998). Currently, the USEPA ranks sediment as one of the top ten pollutants of concern and the subject of numerous Total Maximum Daily Load (TMDL) studies throughout the country. Similar conclusions have been found universally around the world as evidenced by continued evaluation of prediction tools (Jetten et al. 1999). Soil erosion models that evolved can be separated into two general categories: physically-based and empirical, with numerous models being developed following both approaches. The premiere erosion models are the physically-based the USDA Water Erosion Prediction Project (WEPP) model (Flanagan and Nearing 1995), the empirically-based USDA Revised Uniform Soil Loss Equation (RUSLE2) model (Foster et al. 2003), and EUROSEM (Morgen et al. 1998). None of these methods specifically addresses ephemeral gullies. Ephemeral gullies are channelized flow areas formed downslope of rills or rill networks in locations controlled primarily by microrelief expressed by tillage 
and are small enough to be repeatedly obliterated by normal tillage operations. In addition to the volume of soil eroded from the gullies, ephemeral gullies act as delivery channels for surface erosion. The WEPP model (Flanagan and Nearing 1995) and the Ephemeral Gully Erosion Model(EGEM) (Woodward 1999) predict ephemeral gully erosion with physical process algorithms but are restricted in application because they require topographic position and gully length as input parameters that are not easily determined by conventional methods in watershed scale assessments (Teasdale and Barber 2008).

This research used aerial imagery to quantify ephemeral gully locations and losses in a predominately agricultural watershed. This information was then used to develop an Erosion Potential Index (EPI) that uses high resolution aerial imagery combined with readily available soils information and a digital elevation model to predict the location of ephemeral gully development. Actual gully locations were compared to the EPI predicted locations to verify the procedure.

\section{STUDY AREA}

The Palouse Prairie agricultural region of the Pacific Northwest experiences among the highest erosion rates in the USA (Fig. 1). Although conversion to no-till is helping reduce the problem, average annual erosion ranges from 10 to 30 tons per acre on conventionally tilled

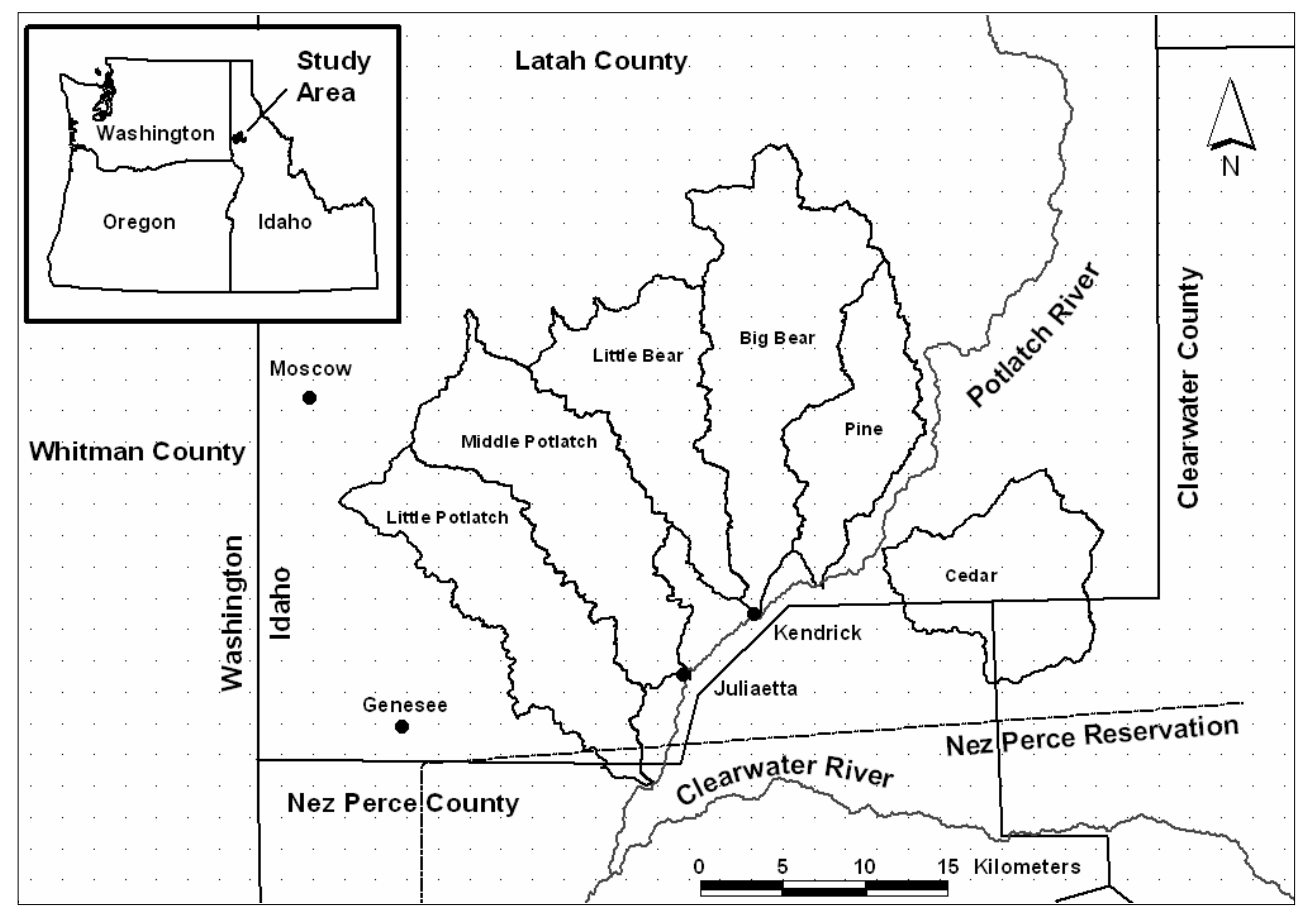

FIGURE 1. Location of Study Area (Teasdale and Barber 2009) 
agricultural land (Michalson et al. 1998). This study occurred in the Potlatch River basin. The total area of the basin is 1540 $\mathrm{km}^{2}\left(590 \mathrm{mi}^{2}\right)$. The upper watershed is predominately forestland of mixed ownership. The southern part of the watershed is the easternmost extension of the Palouse prairie and is dissected by deep canyon lands of the lower tributary drainages. Land use is predominantly dryland agriculture intermixed with areas of rural residential development. The study area covers the $736 \mathrm{~km}^{2}\left(284 \mathrm{mi}^{2}\right)$ of land in the lower Potlatch River basin. The six basins (Big Bear, Cedar, Little Bear, Little Potlatch, Middle Potlatch, and Pine Creek) located in the lower watershed are part of the Northwestern Wheat and Range Region. The long-term average annual precipitation is $647 \mathrm{~mm}$ (25.5 in) recorded approximately $7 \mathrm{~km}$ west of the Potlatch basin boundary.

\section{METHODOLOGY AND RESULTS}

The locations of the gullies and estimate of the actual quantity of ephemeral gully erosion used a considerable amount of high resolution aerial imagery. The aerial imagery was acquired using digital natural-color aerial imaging equipment onboard a Cessna 182 single engine fixed wing aircraft (Teasdale 2005). GPS equipment in the aircraft provided flight line navigation guidance and recorded the imaging ground track. While imaging, the aircraft was typically flown at an altitude of around 800 meters (2500 feet) above the ground to produce imagery with a ground pixel resolution (GPR) of about 0.2 meters ( 8 inches).

The actual ground coverage of the images represented approximately $62 \%$ of the overall agricultural lands in the watershed due to sampling lines flown. In that area, a total of 1004 ephemeral gully systems were identified by aerial survey methods in the six primary basins which provided more than enough for statistical comparison.

A watershed estimate of the volume of soil eroded by ephemeral gullies is computed from three morphological parameters: total length of gully channels, average channel width and average channel depth. Although the precise initiation point of the gully is sometimes difficult to ascertain, total gully lengths can be easily measured to within a few meters using the aerial images. Ephemeral gullies are part of the continuum of erosion with the initiation point located at the transition between rill erosion channels to a topographically convergent concentrated flow erosion channel. The typical zone of uncertainty is between 2 and 10 meters in length and results in an error of less than 3\%. Based on 229 measurements, ephemeral gully widths varied from $0.2 \mathrm{~m}$ to $1.7 \mathrm{~m}$ wide with an average width of approximately $0.6 \mathrm{~m}$. The standard deviation was $0.24 \mathrm{~m}$. The $95 \%$ confidence interval of the mean is 0.56 $\pm 0.03 \mathrm{~m}$.

Ground level photographic observations of numerous ephemeral gullies in the study region show that ephemeral gullies during the winter were mostly approximately $0.2 \mathrm{~m}$ deep. Several ephemeral gullies were observed and measured in the field to support the general observation, however obtaining landowner permission to access private lands proved very difficult.

Based on the length, width and depth information, the average ephemeral gully 
erosion observed is estimated at 49.9 $\mathrm{mton} / \mathrm{km}^{2}$ (0.22 U.S. tons/acre). As summarized in Table 1, the areal ephemeral gully erosion rates varied from $33.6 \mathrm{mton} /$ $\mathrm{km}^{2}$ (0.15 U.S. tons/acre) in the Big Bear Creek basin to $88.4 \mathrm{mton} / \mathrm{km}^{2}$ (0.39 U.S. tons/acre) in the Middle Potlatch Creek basin. While these quantities represent less than $10 \%$ of the RUSLE2 surface erosion rates for the Potlatch agricultural watersheds (shown in column 7), much of the surface erosion was transported in the ephemeral gullies prior to being discharged to the creeks.

High resolution aerial imagery has been shown to produce an accurate assessment of gully characteristics and basin sediment yield at a point in time. Ephemeral gullies observed at the end of an erosion cycle are a manifestation of the preceding weather, basin hydrologic condition and the erosion sensitivity of the basin land cover. Each of these factors must be considered in development of a predictive physical model of ephemeral gully initiation and development (Teasdale 2005). A simpler empirical approach based on readily available remote sensing and GIS data was applied in this project. Late fall LANDSAT 7 imagery was used to provide a good indication of the location and extent of agricultural fields that have been tilled and have low surface residue. Overall, these fields are the most hydrologically sensitive.

Experimentation with various indices showed that low residue fall tilled fields could be identified with a normalized difference index (NDI) using the October 2002 LANDSAT 7 shortwave infrared bands (5 and 7). This index is computed:

$$
N D I=\frac{B 5-B 7}{B 5+B 7}
$$

where $B 5$ and $B 7$ are the Landsat 7 band 5 and band 7 reflectances, respectively. A threshold NDI value of 0.15 discriminated the low residue fields from other land cover types reasonably well throughout the study region. The NDI threshold value was determined by trial and error comparison of the LANDSAT image, a trial NDI grid and the high resolution aerial images. A NDI threshold value of 0.15 may not be appropriate for other regions.

The NDI only indicates the presence of low surface residue soils and thus is not a complete indicator of erosion susceptibility. Two other important factors: soil erodibility and slope were included in a composite index. Soil erodibility for the study region was determined from

TABLE 1. Estimate of ephemeral gully erosion in the lower Potlatch basin

\begin{tabular}{|l|c|c|c|c|c|c|}
\hline Basin & $\begin{array}{c}\text { Average } \\
\text { width } \\
{[\mathrm{m}]}\end{array}$ & $\begin{array}{c}\text { Average } \\
\text { depth } \\
{[\mathrm{m}]}\end{array}$ & $\begin{array}{c}\text { Erosion } \\
\text { volume } \\
{\left[\mathrm{m}^{3} / \mathrm{km}^{2}\right]}\end{array}$ & $\begin{array}{c}\text { Gully } \\
\text { erosion } \\
{\left[\mathrm{mton} / \mathrm{km}^{2}\right]}\end{array}$ & $\begin{array}{c}\text { Gully } \\
\text { erosion } \\
\text { [ton/acre] }\end{array}$ & $\begin{array}{c}\text { Mean surface } \\
\text { erosion } \\
{[\text { ton/acre] }}\end{array}$ \\
\hline Big Bear & 0.6 & 0.2 & 28.0 & 33.6 & 0.15 & 3.57 \\
Cedar & 0.6 & 0.2 & 33.7 & 40.4 & 0.18 & 2.33 \\
Little Bear & 0.6 & 0.2 & 45.2 & 54.2 & 0.24 & 2.87 \\
Little Potlatch & 0.6 & 0.2 & 29.9 & 35.9 & 0.16 & 6.85 \\
Middle Potlatch & 0.6 & 0.2 & 73.7 & 88.4 & 0.39 & 5.18 \\
Pine & 0.6 & 0.2 & 37.4 & 44.8 & 0.20 & 4.23 \\
\hline
\end{tabular}


the NRCS Soil Survey Geographic (SSURGO) database. Terrain slope was determined by digital analysis of the USGS 10-meter DEM. Threshold values for slope and soil erodibility were initially estimated based on a sensitivity analysis using GIS. As a result, the Erosion Potential Index (EPI) was determined by three criterion: 1) a NDI less than 0.15 , 2) a DEM ground slope greater than 15 percent, and 3) a soil erodibility greater than 0.4 . The applicability of these values was verified in this work using high resolution digital natural color aerial images acquired along a single transect. The red areas shown in Figure 2 represent the overlapped layers meeting or exceeding these criteria. The red areas represent the locations where conservation tillage practices, stream set-backs, or other best management practices would provide the most benefit in terms of reducing sediment loads to nearby streams.

\section{DISCUSSION}

Compared to the long-term conservation planning rill and interrill surface erosion rates predicted by the RUSLE2 model shown in Table 1, the sediment load directly from ephemeral gullies in the Potlatch subbasins is relatively small representing only 2.3 to 7.7 percent of the total surface sediment load. While these percentages may change somewhat due to climatic weather conditions (particularly rain-on-snow events), the average sediment yields from ephemeral gullies found in this particular watershed do not represent significant amounts of soil loss compared to the USDA tolerance value. However, inspection of the aerial images

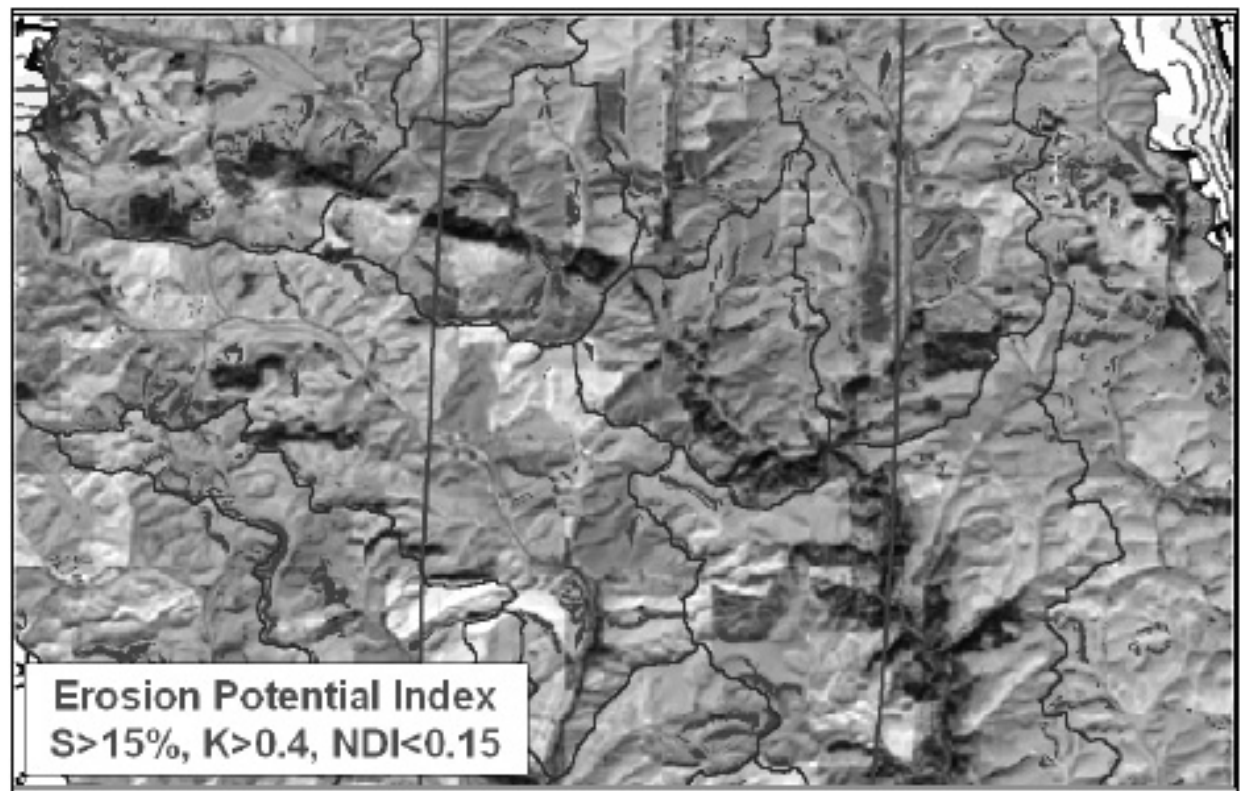

FIGURE 2. Erosion susceptible soils (shown in red) identified by the Erosion Potential Index in the northwestern sections of the Little and the Middle Potlatch Creek Basins (Teasdale and Barber 2009) 
and field verification of connectivity between gullies and streams reveal that ephemeral gullies represent the primary collection and transport network for all surface sediment loading rates. Therefore, locating and prioritizing BMPs for sediment control can be done quickly and accurately using the aerial assessment strategy.

Rather than focusing on expensive analysis at the watershed scale, the EPI approach was found to narrow down the land area considerably and thus allow for more target analysis. Comparison with high resolution visual analysis indicated generally good agreement between the index and actual field conditions. Accuracy of the 10-m DEM seemed to be adequate buy Lidar imagery would help the precision of the prediction tool considerably.

\section{CONCLUSIONS}

Seasonal high-resolution digital aerial imagery provided an efficient means to detect ephemeral gullies with remote sensing and GIS techniques. Ephemeral gullies were synoptically measured on 74,650 ha $(181,990 \mathrm{ac})$ of agricultural lands. The areal ephemeral gully erosion rate for the Potlatch basin agricultural lands averaged $49.9 \mathrm{mton} / \mathrm{km}^{2}$ (0.22 U.S. tons/acre) and varied from $33.6 \mathrm{mton} /$ $/ \mathrm{km}^{2}$ (0.15 U.S. tons/acre) in the Big Bear Creek basin to $88.4 \mathrm{mton} / \mathrm{km}^{2}$ (0.39 U.S. tons/acre) in the Middle Potlatch Creek basin. Ephemeral gully erosion for individual fields can be higher than the average values for the watershed but none of the values estimated in the Potlatch River basin exceeded the USDA total soil loss tolerance value of 5 tons per acre per year for soils in the study area.

The EPI methodology provides an inexpensive way to identify agricultural fields with increased potential for ephemeral gully erosion on large watershed scales from readily available remote sensing and GIS database information. The EPI analysis can be updated with current Landsat imagery prior to the onset of the winter erosion period in the inland Northwest. The EPI methodology can be used in erosion studies, evaluation of waterway sedimentation hazard potential, planning of soil conservation best management practice implementation, and development of drinking water source water protection plans.

\section{REFERENCES}

FLANAGAN D.C. and NEARING M.A., 1995: Water Erosion Prediction Project (WEPP) Hillslope Profile and Watershed Model Documentation, NSERL Report No 10. National Soil Erosion Research Laboratory, West Lafayette, IN.

FOSTER G.R., YODER D.C., WEESIES G.A., McCOOL D.C., McGREGOR K.C. and BINGER K.C., 2003: User's Guide: Revised Universal Soil Loss Equation Version 2 (RUSLE2), USDA-Agricultural Research Service, Washington DC.

JETTEN V., ROO A.D. and FAVIS-MORTLOCK D., 1999: Evaluation of Field-scale and Catchment-scale Soil Erosion Models, Catena, 37(3-4), pp 521-541.

MICHALSON E.L., PAPENDICK R.I. and CARLSON J., 1998: Conservation Farming in the United States: the Methods and Accomplishments of the STEEP Program," CRC Press, Boca Raton, FL.

MORGAN R.P.C., QUINTON J.N., SMITH R.E., GOVERS G., POESEN J.W.A., AUERSWALD K., CHISCI G., TORRI D. and STYCZEN M.E., 1998: The European Soil Erosion Model 
(EUROSEM): A Dynamic Approach for Predicting Sediment Transport from Fields and Small Catchments, Earth Surf. Process. Landforms, 23, pp 527-544.

TEASDALE G.N., 2005: Satellite and Aerial Imaging in Characterization, Hydrologic Analysis and Modeling of Inland Watersheds and Streams, Ph.D. Dissertation, Washington State University, Pullman, WA.

TEASDALE G.N. and BARBER M.E., 2008: Aerial Assessment of Ephemeral Gully Erosion from Agricultural Regions in the Pacific Northwest, ASCE Journal of Irrigation and Drainage Engineering, 134(6), pp 807-814.

WOODWARD D.E., 1999: Method to Predict Cropland Ephemeral Gully Erosion, Catena 37(3-4), pp 393-399.

Streszczenie: Krótkotrwała erozja wawozowa na obszarach rolniczych $w$ pótnocno-zachodnim regionie Pacyfiku, USA. W pracy przedstawiono nowa metodykę prognozowania wielkości i miejsc występowania erozji wąwozowej w skali zlewni, którą sprawdzono na podstawie badań przeprowadzonych na obszarze o łącznej powierzchni $736 \mathrm{~km}^{2}$, w sześciu zlewniach mniejszych cieków położonych w środkowej części zlewni rzeki Potlatch. W badaniach wykorzystano zdjęcia lotnicze wysokiej rozdzielczości oraz wyniki pomiarów terenowych parametrów morfologicznych krótkotrwałych wąwozów erozyjnych, na podstawie których stworzono bazę danych GIS. Uzyskane wyniki badań posłużyły do opracowania Indeksu Erozji Potencjalnej (EPI), do określenia którego wykorzystano obrazowania satelitarne LANDSAT w połączeniu $z$ numerycznym modelem terenu oraz dostępnymi informacjami o glebach. W celu weryfikacji procedury wykorzystano zdjęcia lotnicze wysokiej rozdzielczości do określenia ilościowego lokalizacji wąwozów erozyjnych, a następnie porównano z wartościami EPI, wskazującymi przewidywane miejsca występowania wąwozów. Zdjęcia lotnicze wysokiej rozdzielczości wykorzystano również do oceny ilościowej wielkości erozji gleb spowodowanej erozją wąwozową w zlewni rzeki Potlatch.

\section{MS. received April 2010}

Author's address:

\section{Michael E. Barber}

Professor of Civil and Environmental Engineering Washington State University

PO Box 642910

Pullman, Washington, USA 99164-2910

meb@wsu.edu 